\title{
Kormányzati pénzügyi felelősség, kiadási hatékonyság és állami versenyképesség
}

\section{CSATH MAGDOLNA}

\author{
„Tervezhető, az adófizetők pénzét kímélő, a hatékonyságot \\ és versenyképességet elősegítő szabályozást hozhat a közigazgatásban \\ a kormányzati igazgatásról szóló 2018. évi CXXV. törvény." ${ }^{1}$
}

Minden nemzeti kormány felelös azért, hogy müködésével a lehetö legnagyobb értéket teremtse a társadalom számára, ezzel növelje a nemzeti vagyont és biztositsa a lakosság életszinvonalának folyamatos javulását. Az értékteremtés módszere a hatásos, hatékony állami költségvetés és kiadásmenedzsment. A hatékonyság azt jelenti, hogy a mindenkori kormány a lehetö legjobb minöségü szolgáltatást nyújtja a társadalomnak a lehetö legalacsonyabb költséggel.

A hatásosság pedig a nemzeti célok és prioritások kijelölésének és a programok kidolgozásának minöségét méri.

A cikk a magyar közkiadások mint „input” tényezők, és ezek gazdasági és társadalmi hatásai közötti kapcsolatokat elemzi nemzetközi összehasonlitásban. A közkiadások szerkezetét abban az összefüggésben vizsgálja, hogy annak egyes elemei milyen hatást gyakorolnak egyes gazdasági és társadalmi mutatókra, és hogy közben biztositott-e az elszámoltathatóság, az átláthatóság és az emberi jogok tiszteletben tartása.

A cikk következtetése, hogy bár módszertanilag nem könnyü kimutatni a közkiadás-menedzsment és annak gazdasági-társadalmi következményei közötti kapcsolatokat, de az adatok statisztikai elemzése rávilágithat a költségvetési folyamatok bizonyos gyenge pontjaira. Továbbá ráirányithatja a figyelmet a kormányzati struktúra és az intézményrendszeri képességek olyan területein szükséges további vizsgálatokra, amelyek szintén befolyásolják a kiadásmenedzsment hatékonyságát.

Kulcsszavak: állami értékteremtés, kiadásmenedzsment hatékonysága, ráfordítás-eredmény, humán tőke

1 Elhangzott a Magyary Napok 2019 címü, a Nemzeti Közszolgálati Egyetemen 2019. június 13-án tartott konferencián. 


\title{
The Financial Responsibility of Government, Expenditure Efficiency and State Competitiveness
}

\begin{abstract}
Any national government is responsible for creating the largest possible added value for the society, as this is the way to increase the wealth of the nation, and secure improving living standards for the population. Efficient and effective government budgeting and expenditure management is the way to value creation. Efficiency means offering the highest quality service at the lowest possible cost to society. Effectiveness is explained by how the national objectives and priorities are established, and policy programs are elaborated.

This article explores relationships between Hungarian public spending as inputs and their effects on the economy and society as outcome in international comparison. The structure of public spending is analysed in the context of how the different elements affect economic and social indicators keeping in mind the importance of accountability, transparency and human rights.

The article concludes that although it is not easy methodologically to find a correlation between public expenditure management and its effects on the economy and society, still statistical data analysis can highlight weaknesses in how efficiently resource allocation is managed in the budgetary process.

It can also direct attention to necessary further explorations into the fields of governance structure and institutional capacities which also affect efficiency of expenditure management.
\end{abstract}

Keywords: state value creation, expenditure management efficiency, inputoutcome, human capital

\section{Bevezetés}

Korunk széles körben vitatott kérdése, hogy mitől lesznek sikeresek a nemzetek. A legfontosabb sikerfeltételek között megtaláljuk a kormányzati képességeket, a hatékony kormányzást és az állami értékteremtést.

Ez utóbbival kapcsolatos általános vélemény, hogy a kormányok úgy járulhatnak hozzá leginkább a nemzet gyarapodásához és fejlődéséhez, ha a lehető leghatékonyabban hasznosítják a rendelkezésre álló nemzeti erőforrásokat, beleértve a pénzügyi, természeti és humán erőforrásokat is. Az erőforrásokkal való gazdálkodást jellemző legfontosabb dokumentum a költségvetés, amely egyrészről a mindenkori gazdaságpolitika számokba öntése, másrészről a prioritások megjelenítése. Kifejezi, hogy a gazdasági döntéseket, a lehetséges irányok közötti választást milyen értékrend 
irányítja. Hiszen, ahogyan Schiavo-Campo fogalmaz, ${ }^{2}$ ha „A” témára többet költünk, akkor a többleteket nem költhetjük „B”-re, vagy ha a gazdaság és a társadalom bizonyos szereplői esetén csökkentjük az adókat, akkor nyilvánvalóan máshonnan kell a hiányt új adók vagy megemelt adók formájában pótolni. Így aztán a nemzeti költségvetést akár a nemzet lelkének is nevezhetjük. Egyes nézetek szerint a költségvetés és az emberi jogok között is összefüggés áll fenn, hiszen a költségvetésnek biztosítania kell nemcsak a gazdasági, hanem a társadalmi fejlődést is. Nem fejezheti ki ezért csak szűkebb körök érdekeit, mentesnek kell lennie a korrupciós lehetőségektől, és biztosítania kell az átláthatóságot valamint a számonkérhetőséget. Nem tesz eleget például egy költségvetés ezeknek a követelményeknek akkor, ha az egyes gazdasági szereplőknek nyújtott állami támogatásokat a kormány nem indokolja, illetve ha az adott támogatási összegeket titkosítja. A cikk a kormányzás néhány meghatározásával indul, majd vizsgálja a kormányzás egyik legfontosabb dokumentuma, a költségvetés főbb jellemzőit. Ezt követően számba veszi az állami kiadások fó tételeit, és rámutat a kiadásokkal kapcsolatos hatékonysági elvárás fontosságára, mérhetőségére.

A cikk a kiadási hatékonysággal összefüggésben elsősorban a kiadott összegek - inputok - és a velük elért társadalmi-gazdasági hatások - outcome-ok - összhangját hangsúlyozza.

A hatékonyság mérése azonban nem könnyủ feladat. A nemzetközi kutatások egy része elsősorban a kiadások gazdasági hatásaira, például a hiány alakulására vagy a versenyképességi pozícióra összpontosítja a figyelmét.

Más közelítések az emberi jogok oldaláról vizsgálják a kiadások hatásait kiemelve azok különböző élethelyzetben lévő emberekre, a társadalmi egyenlőtlenségek alakulására, illetve a tudáshoz, egészséghez és tiszta természeti környezethez való jogok érvényesülésére való hatását. Ebben a cikkben a gazdasági hatások mellett elsősorban az állami kiadások és az azok által befolyásolt társadalmi jellemzők összefüggéseire fordítjuk figyelmünket. Vizsgáljuk a magyar állami kiadási szerkezetet nemzetközi összehasonlításban, majd a főbb kiadási tételek és a termékenység, várható élettartam, valamint a korai halálozás miatti munkaerő-veszteség valószínű kapcsolatait keressük.

A cikk egy, a kormányzási hatékonyság átfogó mérésével kapcsolatos kutatómunka első állomásának eredményeit összegzi. A munka folytatásaként az állami költségvetési kiadások hatékonyságát további gazdasági-társadalmi területeken mért hatások összevetésével tervezzük elemezni, illetve megkísérelünk egy több tényezőt kombináló, kompozit mutatót szerkeszteni, amelynek alapján a magyar kormányzás költségvetési eredményességét, a kiadások hatékonyságának mértékét nemzetközi összehasonlításban is mérni lehetne. A költségvetés bevételi oldala szempontjából lényeges adópolitika és a konkrét adózási rendszer lehetséges változatait, illetve azok hatékonyságát ebben a kutatási szakaszban részletesen nem vizsgáljuk.

2 Schiavo-Campo 2017. 


\section{Kormány, kormányzás, kormányzati pénzügyi felelősség}

Boadway és Wildasin klasszikus meghatározása szerint a kormányok ${ }^{3}$ olyan intézmények, amelyek megtestesítik a kollektív döntéshozatalt, és az adózáson, a kiadásokon, a felvett kölcsönökön, a szabályozásokon keresztül befolyást és törvényeken alapuló hatalmat gyakorolnak a gazdasági szereplők, valamint az állampolgárok felett.

Kaufmann, Kraay és Mastruzzi rövidebben fogalmaz: ${ }^{4}$ szerintük a kormányzás az a mód, ahogyan a mindenkori kormány a hatalmat gyakorolja, az ország gazdasági és társadalmi fejlődése érdekében az erőforrásokat hatékonyan hasznosítja.

Rothstein és Teorell a kormányzás minőségéről beszél. ${ }^{5}$ A kormányzás minősége pedig a világos és következetes jogszabályokkal, a korrupció kordában tartásával, a jól müködő demokratikus intézményrendszerrel és a kormányzati munka hatékonyságával mérhető. Eszerint jó minőségű a kormányzás, ha az állam hatékonyan, jó minőségben és költségtakarékos módon nyúitja a szolgáltatásokat az állampolgárok számára.

Acemoglu és Robinson a jó kormányzás és a gazdasági eredményesség között talál összefüggést ${ }^{6}$ azt bizonyítva, hogy egy ország sikeres gazdasági fejlődésének szükséges alapfeltétele a jó kormányzás.

Mások fontos jellemzőnek tartják a több szempont szerinti elszámoltathatóságot is.

Newell és Wheeler szerint ${ }^{7}$ a kormányzás elszámoltathatósága ${ }^{8}$ három jellemzővel írható le:

- transzparencia: a polgárok hozzáférnek olyan információkhoz, amelyek segítségével megismerhetik az állami döntéseket, azok pénzbeli kihatásait, továbbá azt, hogy a döntések mennyire hatékonyan valósultak meg;

- válaszadási kötelezettség: ${ }^{9}$ a polgároknak joga van arra, hogy kérdéseket tegyenek fel az állami cselekedetekkel kapcsolatban, és kérdéseikre választ kapjanak;

- számonkérhetőség: $:^{10}$ a polgároknak lehetőségük van arra, hogy az államot bizonyos normák betartására rákényszeríthessék.

Vagyis a számonkérhetőség elsősorban az állam és a polgárok közötti kapcsolatrendszert írja le: azt, hogy az államot milyen mértékben vonhatják felelősségre cselekedeteiért az állampolgárok. ${ }^{11}$

3 A szerzők felhívják a figyelmet arra, hogy az „államot” és a „kormányt” gyakran összekeverik, pedig nem ugyanarról a fogalomról van szó. Szerintük az állam alapvetően egy szuverén földrajzi egység, amely kormányai által alkotott törvények és politikák szerint müködik. A kormány pedig az állam adminisztratív apparátusa, az az intézmény, amely kidolgozza a törvényeket és politikákat, és végrehajtja/végrehajtatja azokat. BOADWAY-WILDASIN 1984.

4 Kaufmann-KraAy-Mastruzzi 2010.

5 Rothstein-TeOrell 2008.

6 ACEMOGLU-Robinson 2012.

7 NEWELL-WHEELER 2006.

8 Angol megfelelője: „accountability”.

9 Angol megfelelője: , answerability”.

10 Angol megfelelöje: „enforceability”.

11 Accountability and Democratic Governance: Orientations and Principles for Development 2014. 
Korunkban az adatokkal való rendelkezés a számonkérhetőség fontos feltétele. Pontos és időben rendelkezésre álló adatok nélkül nem lehet megbízható döntéseket hozni sem az üzleti, sem pedig az állami szférában. Azonban világos szabályokra van szükség a tekintetben, hogy ki milyen adatokat tárolhat, elemezhet és használhat fel. Az egyik legnagyobb adattulajdonos maga az állam. Walker szerint ${ }^{12}$ az államnak - többek között - azért kell elérhetővé tennie a rendelkezésére álló adatokat, hogy müködésének hatékonyságát értékelni lehessen. Különösen fontos és az állampolgárok számára elérendővé teendő adat, hogy mire és mennyit költ az állam. Az adatok elérhetősége egyben jó lehetőséget kínál a korrupció elleni fellépésre is.

Farrell és Goodman arra figyelmeztet, ${ }^{13}$ hogy a kormányzás fontos jellemzöje kell, hogy legyen a racionális, elemzéseken alapuló döntéshozatal, amelyet úgy is jellemezhetnénk, hogy egyre jobb minőségű szolgáltatást nyújt a polgároknak egyre hatékonyabban, vagyis csökkenő költségekkel. A szerzők szerint a döntéshozatali hatékonyság növelése jelentős költségmegtakarítással jár, és ezért csökkenti az állami kiadásokat. Ez azonban feltételezi megfelelő mérési rendszerek alkalmazását, valamint a teljesítmények nemzetközi összehasonlítását. Ilyen mérés lehet, hogy például az egészségügyre fordított összegek növelése milyen hatással van a halálozási statisztikák javulására, valamint hogy ez az érték mennyire jónak tekinthető más országok adataival összehasonlítva. A mérés maga is hozzájárul az állami döntések transzparenciájának növeléséhez, az állampolgárok informálásán keresztül a döntéshozatallal kapcsolatos objektív véleményük kialakulásához. Egyre gyakrabban vetődik fel a kormányzati hatékonyság kapcsán az értékteremtés is. Egy brit kormánytanulmány ${ }^{14}$ szerint az „értéket teremteni a pénzért” fogalom azt jelenti, hogy minden állami pénzt úgy szabad csak elkölteni, hogy azért a lehető legnagyobb érték jöjjön létre a társadalom számára. Ez feltételezi a közpénzek elköltésével kapcsolatos teljes átláthatóságot és felelősségre vonhatóságot. ${ }^{15}$

A tanulmány arra a következtetésre jut, hogy az erőforrások - amelyek általában szűkösen állnak rendelkezésre - felhasználásának hatékonyságát végső soron az ezzel elért társadalmi-gazdasági hatással lehet lemérni.

\footnotetext{
12 WALKer 2016.

13 FARrell-Goodman 2013.

14 A tanulmány, amely 2010-ben készült, az állami kiadások és azok eredményei közötti összefüggések vizsgálatára dolgozott ki módszertant.

15 BARNett et al. 2010.
} 
A folyamatot az 1. ábrával szemléltetik.

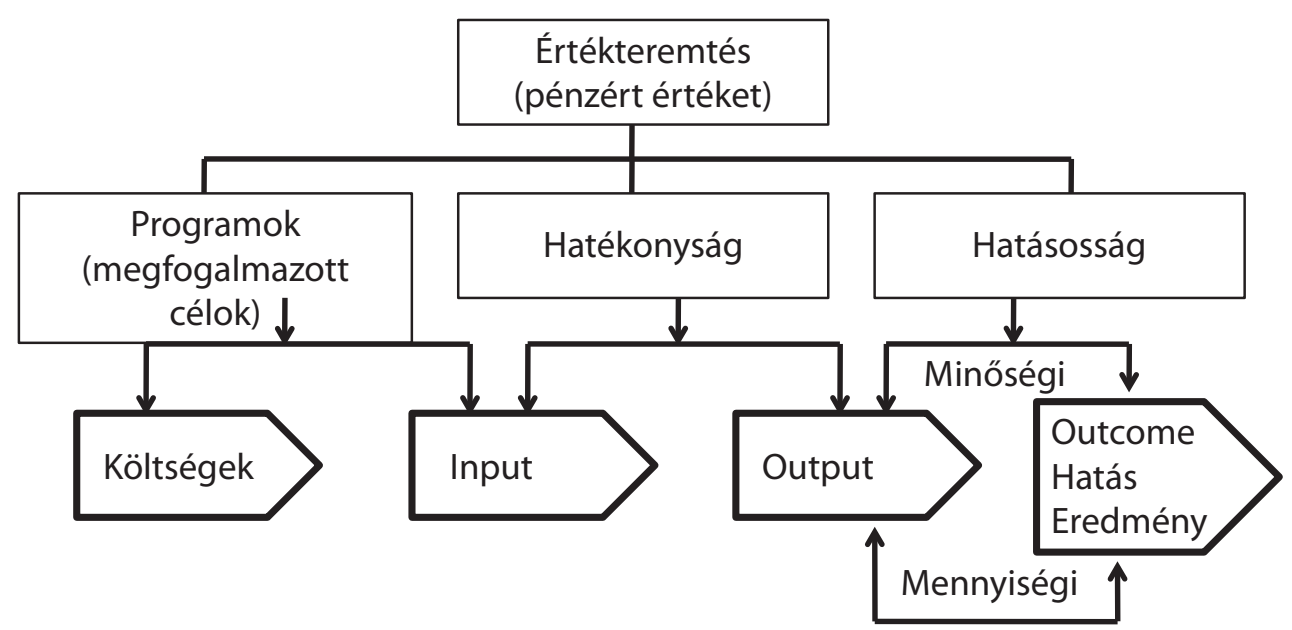

1. ábra: A közpénzek hatékony hasznositását ellenőrzö folyamat Forrás: BARNETT et al. (2010) alapján a szerzö szerkesztése

A programok jelentik az állami ráfordítással, azaz költségekkel finanszírozott különböző projekteket. A költségek, beleértve a közvetlen és közvetett költségeket egyaránt, az értékteremtő folyamat inputjai. Az „output” a közvetlen, látható eredmény. Például, ha egy kórház esetén a program korszerủ diagnosztikai eszközök beszerzését jelenti, akkor az input ezek összes költségét, az output pedig a beszerzett eszközöket jelenti. A hatás, eredmény (outcome) pedig a gyógyító munka így elért javulását, azaz a társadalmi hatást mutatja meg. A program hatékonysága a költségekkel való gazdálkodást méri. A hatékonyság természetesen nem azt jelenti, hogy a költségekkel a minőség rovására kell takarékoskodni.

A hatásosság pedig azt mutatja meg, hogy a programokban kitűzött, elérendő célokat milyen jól választották meg a döntéshozók.

Érdemes felfigyelni arra, hogy a modell szerint az eredményeket nemcsak mennyiségi, hanem minőségi szempontok szerint is értékelni kell. Ilyen lehet például, hogy a beszerzett új diagnosztikai eszközökkel végzett vizsgálatok mennyire „invazívak”, például mekkora fájdalmat okozó beavatkozással járnak.

A mérés eredményeképpen képet kell kapni a következőkről:

- a tervezetthez képest összességében, valamennyi közvetlen és közvetett költség figyelembevételével mennyi lett a végleges kiadás;

- milyen mennyiségi és minőségi mutatókkal mérhető eredmények születtek;

- a költségek és az eredmények összevetésével mért hatékonyság hogyan viszonyul más, hasonló projektek hatékonyságához. 
Az utóbbi vizsgálatokat „benchmarking”, azaz összehasonlító elemzéseknek nevezzük. Lényegük a minél szélesebb körben, lehetőleg nemzetközi szinten végzett összehasonlítások végzése az úgynevezett ,jó gyakorlatok” megismerése érdekében.

A kormányzás gazdálkodásának fontos megjelenése a költségvetés, annak bevételei és kiadásai.

\section{Kormányzás és költségvetés}

A költségvetés a mindenkori kormány egyik legfontosabb gazdaságpolitikai dokumentuma, amelynek tartalma jelentős hatással van az állampolgárok életére.

Schiavo-Campo szerint a költségvetés a gazdaságpolitikai és társadalmi választások tükre. ${ }^{16} \mathrm{~A}$ kormány ezen keresztül mutatja be, hogy a társadalom által ráruházott feladatokat milyen jól látja el, milyen gondosan védi és növeli a nemzeti vagyont. A szerző szerint azokban az országokban, amelyekben gyenge és nem hatékony az intézményrendszer, gyakran az uralkodó elit személyes tulajdonaként gazdálkodik a nemzeti vagyonnal. Az ENSZ különböző dokumentumai hangsúlyozzák, hogy a költségvetés készítése során a kormányoknak figyelemmel kell lenniük az emberi jogokra. ${ }^{17} \mathrm{~A}$ kormányoknak biztosítaniuk kell, hogy az állampolgárok egyrészt hozzájuthassanak a költségvetéssel kapcsolatos valamennyi információhoz, másrészt lehetővé kell tenniük az állampolgári részvételt a tervezési, döntéshozási, megvalósítási és ellenőrzési folyamatban. A kormányok költségvetési felelőssége egyben azt is jelenti, hogy felelősségre vonhatók azért, ahogy a bevételeket megtervezik és begyüjtik, valamint azért, ahogyan és amire azokat elköltik. Az adóbegyűjtésnek és a kiadásoknak egyaránt hatékonyan kell történniük, mert különben a nemzeti erőforrások nem jól hasznosulnak. ${ }^{18}$

A tisztességes és hatékony adózási rendszer megtervezése és működtetése, az adóelkerülés büntetése egyaránt a kormányzati számonkérhetőség fontos szakmai területe. Az OECD szerint ${ }^{19}$ az adózási rendszerek három területen is hozzájárulhatnak a kormányzati képességek javításához:

- a tisztességes és jól megtervezett adózási rendszer hozzájárul a gazdasági növekedéshez, és ezért elfogadhatóvá teszi azt az állampolgárok számára;

- az adók begyüjtése és az adózók ellenőrzése jól működő, hatékony intézményrendszert feltételez, ami jó hatással lehet az intézményrendszer egészére, ezzel a kormányzati képességekre is;

- az állami számonkérhetőség és a felelős állami magatartás javítja az adófizetők állammal szembeni bizalmi szintjét, következőleg szabálykövető magatartását, adózási hajlandóságát.

16 Schiavo-Campo 2017.

17 Ilyenek például: International Covenant on Economic, Social and Cultural Rights (ICESCR, 1966), amely az egészséggel, vagy az ICESCR art. 13 és a Convention on the Rights of the Child (CRC 1989, article 28), amely az oktatáshoz való jogot fogalmazza meg.

18 Realizing Human Rights Through Government Budgets 2017.

19 Citizen-state relations 2010. 
Vagyis az állam feladata több mint az adók beszedése. Az adórendszer segítségével erősítenie kell a gazdaságot és a társadalmat egyaránt.

\section{Mikor tekinthető jónak egy költségvetés?}

A költségvetésnek átláthatónak kell lennie, azaz biztosítani kell a vele kapcsolatos társadalmi vitát. Fontos továbbá, hogy legyenek benne tartalékok azért, hogy ha váratlan események következnének be, akkor fenntartható legyen az egyensúly. Ezzel kapcsolatban lényeges az is, hogy világos felelősségeket fogalmazzon meg a tekintetben, hogy mely intézmények, programok, akciók, fejlesztési projektek mennyi állami forrással gazdálkodhatnak, ráfordításaikkal milyen eredményeket kell elérniük, továbbá, hogy ki a felelős a hatékony végrehajtásért.

Az ellenőrzés lehetőségét a pénzügyi év során folyamatosan biztosítani kell. Az ellenőrzési rendszer működtetésének fontos feladata az indokolatlan túllépések, a rossz gazdálkodásból adódó pocsékolás időben történő észlelése és megakadályozása. Végül a jó költségvetés nem növeli a hiányt és az államadósságot.

A költségvetés készítése során az állampolgárokat érdekelheti, hogy

- milyen gazdaságpolitikai prioritások mentén készül a költségvetés, milyen célokat akar vele elérni a kormány;

- a kitűzött célokra, programokra mennyi pénzt tervez költeni a kormány, és miért annyit;

- mennyi pénzt költ a kormány saját magára, az intézményrendszer fenntartására, müködtetésére;

- a költségvetés kiadásai alapján milyen hatások, fejlődés, előrelépés várható a gazdaságban és a társadalomban;

- mely társadalmi csoportokat milyen mértékben érint a költségvetés akár a bevételi - adózási -, akár pedig a kiadási-ráfordítási, támogatási oldalról;

- milyen gazdaságerősítő, növekedést támogató, továbbá versenyképességet javító következményeket várunk el az állami ráfordításoktól.

A további pontokban foglalkozunk az állami kiadások jellemzőivel nemzetközi összehasonlításban, és kísérletet teszünk néhány jellemző mutató kapcsán a ráfordítások és az elért hatások összevetésére.

\section{Az állami kiadások alakulása és szerkezete}

Közgazdasági viták témája, hogy milyen mértékben vehet részt a mindenkori állam az erőforrások elosztásában. A tökéletes szabad piac hívei szerint az erőforrásokat hatékonyan csak a piaci mechanizmusok képesek elosztani. ${ }^{20}$

20 Tanzi és Schuknecht például maximum a GDP 30\%-ában határozza meg az állami kiadások arányát. 2018-ban az EU-ban ennek a korlátnak egyetlen ország, Írország felelt meg (25,7\%). TANZISCHUKNECHT 1997. 
Ezzel szemben mások, hivatkozva a növekvő környezeti bizonytalanságokra, és a 4. ipari forradalomba való sikeres bekapcsolódás kényszereire főleg az innováció területén jelentős állami részvételt tartanak szükségesnek. ${ }^{21}$

A közgazdasági viták további elemzése helyett vizsgáljuk meg az állami kiadások nagyságát és szerkezetét néhány EU-s ország esetén. A kormányzás prioritásait, értékrendjét, de hatékonyságát is méri, hogy az egyes években hogyan alakul a megtermelt új érték, a GDP arányában az állami kiadások mértéke és szerkezete.

Az 1. táblázatban néhány ország állami kiadásainak GDP-arányos értékét látjuk a 2010-2018 években.

1. táblázat: A teljes állami kiadás a GDP százalékában Magyarországon és néhány további EU-s országban 2010-2018 között

\begin{tabular}{|l|c|c|c|c|c|c|c|c|c|}
\hline \multicolumn{1}{|c|}{ Ország } & $\mathbf{2 0 1 0}$ & $\mathbf{2 0 1 1}$ & $\mathbf{2 0 1 2}$ & $\mathbf{2 0 1 3}$ & $\mathbf{2 0 1 4}$ & $\mathbf{2 0 1 5}$ & $\mathbf{2 0 1 6}$ & $\mathbf{2 0 1 7}$ & $\mathbf{2 0 1 8}$ \\
\hline EU28 & 49,9 & 48,5 & 48,9 & 48,6 & 47,9 & 46,9 & 46,2 & 45,8 & 45,6 \\
\hline Magyarország & 49,3 & 49,5 & 48,5 & 49,4 & 49,5 & 50,1 & 46,8 & 46,9 & 46,5 \\
\hline Csehország & 43,5 & 43,0 & 44,5 & 42,6 & 42,4 & 41,7 & 39,5 & 38,9 & 40,8 \\
\hline Lengyelország & 45,8 & 43,9 & 42,9 & 42,6 & 42,4 & 41,7 & 41,1 & 41,2 & 41,5 \\
\hline Szlovákia & 42,1 & 40,8 & 40,6 & 41,4 & 42,0 & 45,1 & 41,5 & 40,2 & 40,6 \\
\hline Ausztria & 52,8 & 50,9 & 51,2 & 51,6 & 52,4 & 51,1 & 50,3 & 49,2 & 48,5 \\
\hline Németország & 47,3 & 44,7 & 44,3 & 44,7 & 44,0 & 43,7 & 43,9 & 43,9 & 43,9 \\
\hline
\end{tabular}

Forrás: Eurostat

A táblázat azt mutatja, hogy egyrészt a GDP-arányos állami kiadások nagyságát tekintve jelentős a magyar állam szerepvállalása, másrészt, hogy bár a magyar érték csökkenő tendenciát mutat, Ausztria kivételével 2018-ban a vizsgált országok között még mindig a magyar állam GDP-arányos kiadásai a legmagasabbak.

Az állami kiadásokkal kapcsolatban az is fontos kérdés, hogy mire és mennyit költ az állam.

A tipikus állami kiadások között találjuk az általános közszolgáltatásokra, a védelemre, a közbiztonságra, a környezetvédelemre, a lakhatásra, a gazdaság ösztönzésére, az oktatásra, egészségügyre, kultúrára, hitéletre, kikapcsolódásra és a szociális védelemre fordított összegeket. A nemzetközi statisztikák azt mutatják, hogy általában a fejlettebb, gazdagabb országok, illetve az erősebb központi hatalommal jellemezhető országok állami kiadásai magasabbak. Az előbbire Dánia, Finnország, Svédország, az utóbbira Franciaország a példa. Dánia összes állami költése a GDP arányában 2018-ban 51,4\%, Finnországé 53,1\%, Svédországé 49,9\% és Franciaországé $56,0 \%$ volt. A magyar érték pedig 46,5\%, bár mint látjuk, ez is a magas értékek között van: a 9. legmagasabb érték az EU-ban. Ezen belül az említett részterületekre fordított

21 Mazzucato 2011, 2017. 
összegekre csak a 2017. évi adatok állnak rendelkezésre. Az adatokat vizsgálhatjuk a GDP százalékában, ez esetben az adott területekre költött összegek aránya együttesen a GDP-arányos teljes állami kiadást adja meg. További információval szolgál, ha a teljes állami kiadáson belül az egyes részterületeken történt ráfordítások arányát is megvizsgáljuk. Ezek szerint 2017-ben az EU-ban átlagosan a GDP 45,8\%-át költötték el az államok. ${ }^{22}$ Ebből az egyes említett területek GDP-arányosan, illetve a teljes kiadások arányában a 2. táblázat szerint részesedtek.

2. táblázat: Állami kiadások tételei, 2017 (EU28 átlag)

\begin{tabular}{|l|c|c|}
\hline Kiadási tételek & $\begin{array}{c}\text { A GDP arányában } \\
\mathbf{( \% )}\end{array}$ & $\begin{array}{c}\text { A teljes kiadás } \\
\text { százalékában } \\
\mathbf{( \% )}\end{array}$ \\
\hline Általános közszolgáltatások & 5,8 & 12,7 \\
\hline Védelem & 1,3 & 2,9 \\
\hline Közbiztonság & 1,7 & 3,7 \\
\hline Környezetvédelem & 0,8 & 1,6 \\
\hline Lakhatás & 0,6 & 1,3 \\
\hline Gazdaság ösztönzése & 4,0 & 8,9 \\
\hline Oktatás & 4,6 & 10,2 \\
\hline Egészségügy & 7,1 & 15,3 \\
\hline Kultúra, hitélet, kikapcsolódás & 1,1 & 2,3 \\
\hline Szociális védelem & 18,8 & 41,1 \\
\hline Összesen & $\mathbf{4 5 , 8}$ & $\mathbf{1 0 0 , 0}$ \\
\hline
\end{tabular}

Forrás: Eurostat

Az adatokat megvizsgálva azt látjuk, hogy az EU28 országában GDP-arányosan a legtöbbet - a GDP 18,8\%-át - a kormányok szociális védelemre, a legkevesebbet pedig - a GDP 0,6\%-át - a lakhatási problémák állami megoldására fordították. Ez azt jelenti, hogy az összes állami kiadásban átlagosan 41,1\%-ot vettek igénybe a szociális támogatások. Ezt követte az egészségügy $(15,3 \%)$ állami finanszírozása. Most vizsgáljuk meg a megfelelő magyar értékeket. A 3. táblázat első oszlopában a különböző kiadási tételeket a GDP százalékában, a második oszlopában pedig a teljes állami kiadás százalékában látjuk.

A 3-4. oszlop pedig azt mutatja meg, hogy a magyar értékek mennyire térnek el a megfelelő EU28 átlagértékektől. 
3. táblázat: Állami kiadások tételei Magyarországon, 2017

\begin{tabular}{|c|c|c|c|c|}
\hline \multirow[b]{2}{*}{ Kiadási tételek } & \multirow{2}{*}{$\begin{array}{c}\text { A GDP } \\
\text { arányában } \\
(\%)\end{array}$} & \multirow{2}{*}{$\begin{array}{c}\text { A teljes } \\
\text { kiadás } \\
\text { \%-ában (\%) }\end{array}$} & \multicolumn{2}{|c|}{ Eltérés az EU28 átlagtól } \\
\hline & & & $\begin{array}{c}\text { A GDP } \\
\text { aránya esetén }\end{array}$ & $\begin{array}{c}\text { A teljes } \\
\text { kiadás aránya } \\
\text { esetén }\end{array}$ \\
\hline Általános közszolgáltatás & 7,8 & 17,0 & 2,0 & 4,3 \\
\hline Védelem & 1,0 & 2,1 & $-0,3$ & $-0,8$ \\
\hline Közbiztonság & 2,4 & 5,0 & 0,7 & 1,3 \\
\hline Környezetvédelem & 0,4 & 1,0 & $-0,4$ & $-0,6$ \\
\hline Lakhatás & 0,8 & 1,6 & $-0,2$ & 0,3 \\
\hline Gazdaság ösztönzése & 7,1 & 15,0 & 3,1 & 6,1 \\
\hline Oktatás & 5,1 & 10,8 & 0,5 & 0,6 \\
\hline Egészségügy & 4,8 & 10,2 & $-2,3$ & $-5,1$ \\
\hline Kultúra, hitélet, kikapcsolódás & 3,5 & 7,4 & 2,4 & 5,1 \\
\hline Szociális védelem & 14,0 & 29,9 & $-4,8$ & $-11,2$ \\
\hline Összesen & 46,9 & 100 & & \\
\hline
\end{tabular}

Forrás: Eurostat alapján saját számitás

A 3. táblázat szerint Magyarország is a szociális védelemre költötte a GDP arányában és a teljes kiadáson belüli arányt tekintve egyaránt a legtöbbet (14,0\%, 29,9\%). Az EU-s átlagértékhez viszonyítva azonban ez alacsony: GDP-re vetítve 4,8\%-kal, a kiadási arányban pedig 11,2\%-kal marad el az EU-s átlagtól. Hasonlóképpen nagy a lemaradásunk az egészségügyi ráfordítások terén: 2,3\%, illetve 5,1\%-kal vagyunk az EU28 átlagérték alatt. Viszont a gazdasági kiadások, továbbá a kultúra, hitélet és kikapcsolódás tételek esetén a magyar értékek jelentősen meghaladják az EU-s átlagértékeket.

Ezek az értékek nyilvánvalóan prioritásokat, társadalmi-gazdasági célokat is megtestesítenek. Fontos azonban az is, hogy konkrétan milyen kiadás értékekkel, milyen eredményeket ér el a költségvetés, vagyis, hogy milyen hatékonysággal hasznosulnak az állami kiadások.

\section{Az állami kiadások elköltésének társadalmi-gazdasági hatékonysága}

Az állami költések hatékonyságát közvetlenül nehéz mérni. Közvetett mérés lehet, ha az adott területre elköltött állami kiadás gazdasági-társadalmi hatásait próbáljuk meg számszerűsíteni. Példa lehet erre, ha az egészségügyre fordított összegek és a várható élettartam közötti, ${ }^{23}$ vagy az oktatásra költött pénz és az elhelyezkedési lehetőségek közötti kapcsolatokat vizsgáljuk. Viszont tisztában kell lenni azzal, hogy a minőségi javulás nem csak pénzbeli ráfordítások kérdése, továbbá, hogy az adott időpontban elköltött összegek és az eredményekben megmutatkozó hatások között időbeli eltolódás is van, ami közben más hatások is alakítják a ráfordításokkal

23 Erre a témára a következő pontban térünk vissza. 
megtámogatott területeket. A mérési nehézségeket érzékelteti, hogy például a kormány versenyképességi programja ${ }^{24}$ is úgy fogalmaz az egyes állami beavatkozások kapcsán, hogy azok hatása mérsékelt, közepes vagy erős lesz rövid (1-2 év), illetve hosszabb távon (3-5 év).

Az anyag arra is felhívja a figyelmet, hogy régiónkban még mindig magas a magyar állam kiadása. Így fogalmaz: „a GDP-arányos állami kiadások szintje továbbra sem optimális, meghaladják régiós versenytársaink és az euro-övezet átlagát is".25

A program szerint „méreteiben kisebb és hatékonyabb közszférára” lenne szükség. Azonban a hatékonyság mérésének módjára az anyag nem tér ki. Helyette így fogalmaz: „[A]z állami kiadások szükséges mérséklése szempontjából mérlegelendő, hogy a kiadási tételek közül melyek képesek érdemben hozzájárulni a gazdaság hosszútávú növekedéséhez.

Magas fiskális multiplikátor-hatássa ${ }^{26}$ olyan kiadási tételek bírnak, amelyek a humán tőke növelését (például oktatás) és megőrzését (például egészségügy), illetve az infrastruktúra fejlesztését és a kutatási tevékenység ösztönzését szolgálják. A kiadási tételek esetében a ráfordítások nagysága mellett a felhasználás minősége is meghatározó."

A felhasználás minőségén értjük, hogy a megvalósuló projekt értéke nemcsak pénzben mérhető, hanem az általa kínált szolgáltatás minőségével is. A minőség mérésére, a hatékonysághoz hasonlóan, nincsenek egyértelmủ és objektív módszerek. A költségvetés feladatai között említettük a gazdaság erősítését, növelését és a versenyképesség javítását. Nézzük meg most, hogy a gazdaság erősítése szempontjából fontos költségvetési hiány és államadóssági szint, valamint az állami kiadások nagysága között felfedezhetö-e összefüggés. Majd foglalkozunk néhány az oktatást, az innovációt és az egészségügyet érintő összefüggéssel is.

A 2. ábrán azt látjuk, hogy Magyarország és Franciaország esetén egyaránt magas a hiány és az adósságszint, valamint az állam GDP-arányos kiadása, vagyis ezek között az értékek között összefüggés érzékelhető.

24 Program a Versenyképesebb Magyarországért 2019.

25 Megjegyzés: nemcsak az euroövezet, hanem az EU28 országátlagát is meghaladják.

26 „Sokszorosító, tovagyürűző” hatás. Egységnyi kiadás hány egységnyi eredményt hoz létre. 


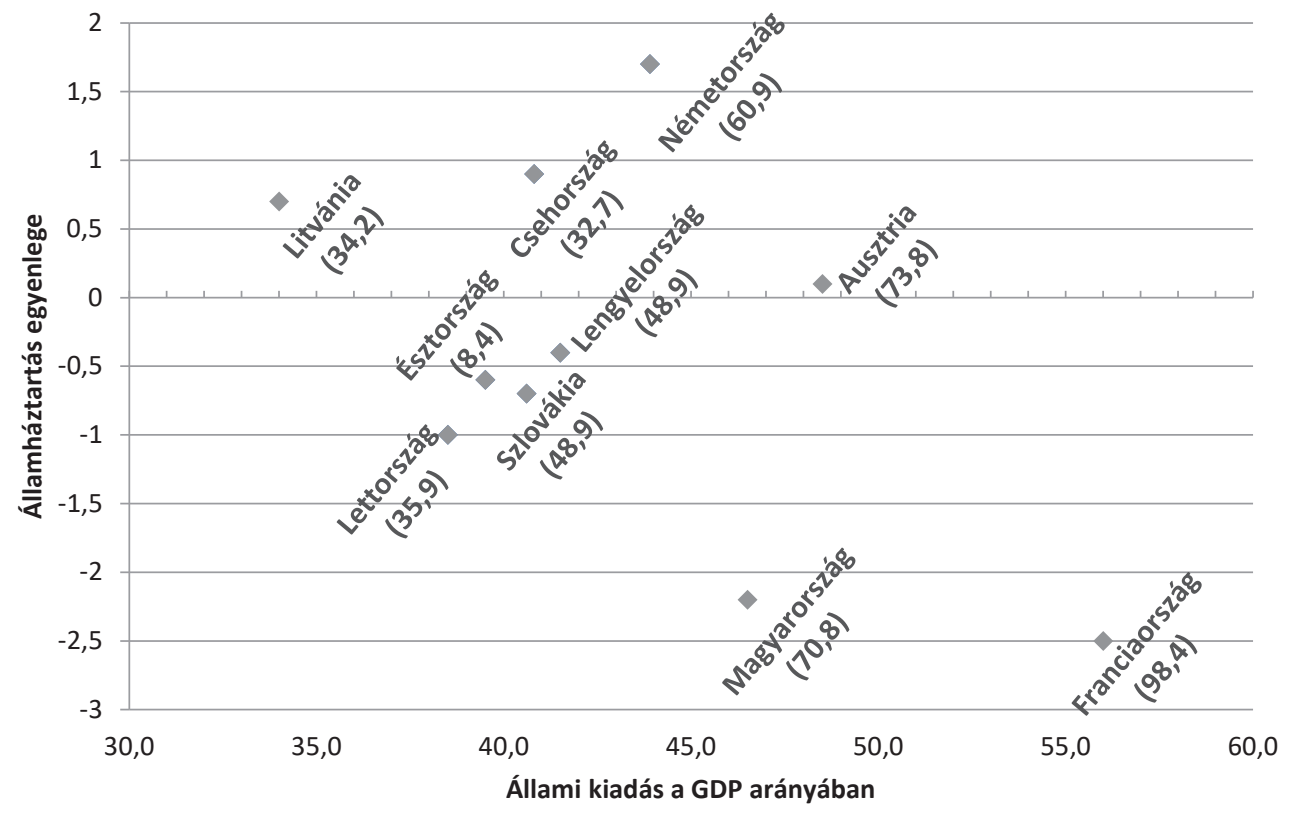

2. ábra: A teljes állami kiadás, a költségvetési hiány és az államadósság a GDP százalékában néhány EU-s országban 2018-ban

Forrás: Eurostat adatai alapján a szerzó szerkesztése

A vizsgált országok közül négy esetén költségvetési többlet van, közülük egyedül Ausztria lépi túl a maastrichti kritériumokban ${ }^{27}$ megállapított $60 \%$-os államadósságszintet. Magyarország hiányszintje a kritériumok alatt van, de így is magas. A V4-ek ${ }^{28}$ között a magyar adatok a legrosszabbak. A költségvetési kiadások szempontjából fontos követelményként említhetjük a versenyképesség javulásához való hozzájárulást is. Különösen fontos lehet a gazdaságra szánt kiadások versenyképességjavító hatása. A 3. ábrán azt látjuk, hogy néhány EU-ország mennyit költött 2017-ben GDParányosan gazdaságára, illetve hogy a kiadás után két évvel, 2019-ben hányadik helyen volt az IMD ${ }^{29}$ versenyképességi listáján.

27 Maastrichti kritériumok: az euroövezethez való csatlakozás kritériumai (maximum 3\%-os költségvetési hiány, 60\%-os államadósság, árstabilitás).

28 V4 országok: Csehország, Lengyelország, Szlovákia, Magyarország.

29 IMD: International Institute for Management Development, Lausanne, Svájc. Nemzetközi vezetőképző és versenyképességkutató intézet. 


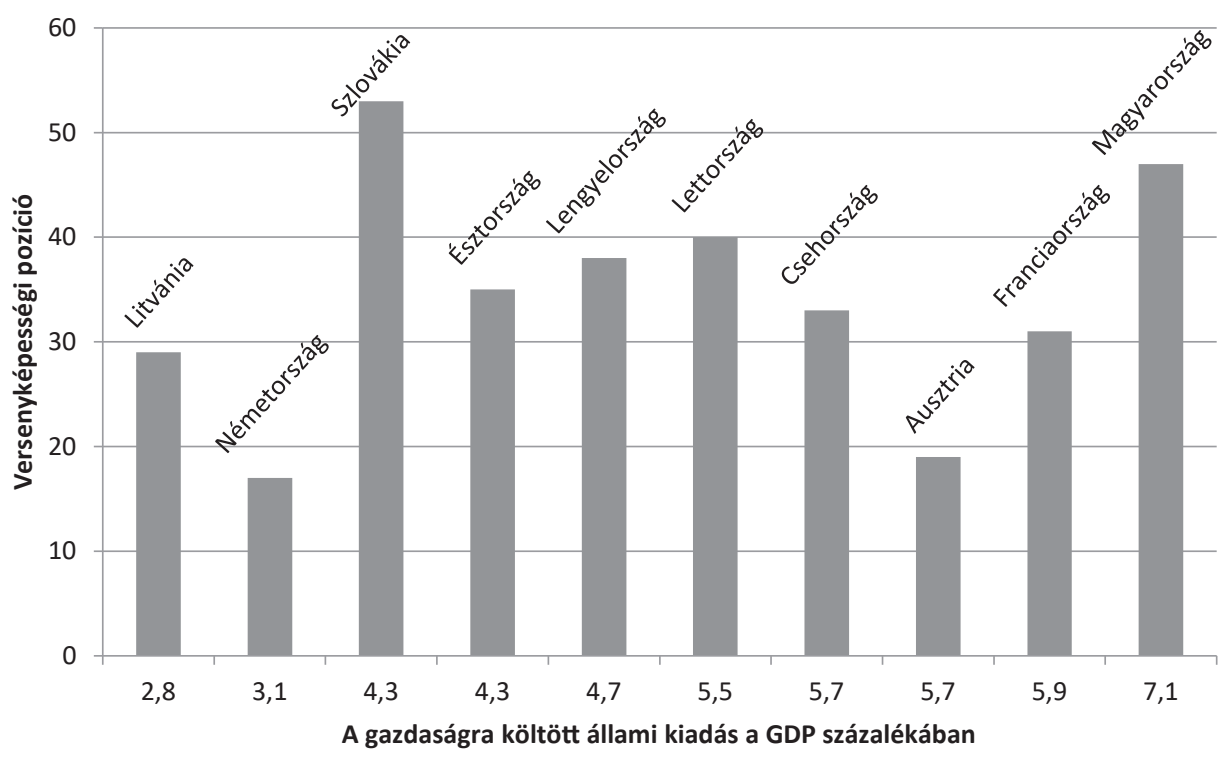

3. ábra: A gazdaságra költött összes állami kiadás a GDP százalékában 2017-ben és a versenyképességi pozíció (IMD 2019) néhány EU-s országban

Forrás: Eurostat és IMD-adatok alapján a szerzö szerkesztése

A 3. ábrán azt látjuk, hogy a legtöbbet Magyarország költötte gazdaságfejlesztésre 2017-ben, viszont az IMD versenyképességi listán a vizsgált országok között csak Szlovákiát előzi meg 2019-ben.

Nyilvánvaló, hogy a gazdaságra fordított összeg befolyásolja a versenyképességet, de további tényezők is hatnak rá. Ahogyan arra a kormányprogram is rámutat, fontos versenyképesség-javító tényező a humán vagyonba, azaz a tudásba és az egészségbe történő beruházás is. Továbbá tekintettel arra, hogy a ráfordítások eredményei időbeli eltolódással jelentkeznek, érdemes az adatokkal kapcsolatban idősorokat vizsgálni.

A 4. táblázatban a V4-ek, Ausztria és Németország adatait látjuk a 2010-2017-es időhorizonton. Az első blokkban azt látjuk, hogy a GDP hány százalékát fordították a gazdaság erősítésére. A 2-3. blokk a GDP oktatásra és az egészségügyre szánt százalékát mutatja. A 4. blokk adatai a kutatás-fejlesztés GDP-ből való részesedését mutatják. Megjegyzendő, hogy ez nem az állami kiadásokat méri egyedül, hanem tartalmazza az üzleti szféra kutatás-fejlesztési ráfordításait is, amelynek alakulását az állam adópolitikával és kedvező üzleti környezettel ösztönözni tudja. A kutatás-fejlesztési ráfordítások vizsgálatát indokolja, hogy valamennyi kapcsolódó kutatás szerint a kutatás-fejlesztés és az innováció jelentős hatással van a versenyképességre. ${ }^{30}$ Végül az 5. blokkban az országok versenyképességi pozícióinak változását látjuk 2010-2017 között az IMD-rangsor alapján.

Például: CSATh 2018; PAlotaI-Virág 2016. 
Kormányzati pénzügyi felelősség, kiadási hatékonyság és állami versenyképesség

4. táblázat: Különböző területekre fordított kiadások aránya az összes kiadáson belül néhány EU-s országban (2010-2017)

\begin{tabular}{|c|c|c|c|c|c|c|c|c|c|}
\hline \multirow{2}{*}{\multicolumn{2}{|c|}{\begin{tabular}{|c|} 
Ország és terület \\
Gazdaságra szánt kiadás
\end{tabular}}} & 2010 & 2011 & 2012 & 2013 & 2014 & 2015 & 2016 & 2017 \\
\hline & & \multicolumn{8}{|c|}{ Gazdaságra szánt kiadás } \\
\hline \multirow{6}{*}{ 1. blokk } & Magyarország & 10,8 & 10,7 & 13,0 & 14,2 & 15,9 & 18,0 & 14,6 & 15,0 \\
\hline & Csehország & 15,2 & 14,9 & 13,8 & 13,7 & 14,8 & 15,6 & 15,1 & 14,6 \\
\hline & Lengyelország & 13,9 & 13,7 & 12,2 & 10,7 & 12,4 & 11,8 & 10,6 & 11,3 \\
\hline & Szlovákia & 11,6 & 11,5 & 11,2 & 11,3 & 11,4 & 14,1 & 10,4 & 10,1 \\
\hline & Ausztria & 12,3 & 12,1 & 12,3 & 12,3 & 14,1 & 12,0 & 11,2 & 11,6 \\
\hline & Németország & 10,2 & 8,2 & 7,8 & 7,3 & 7,1 & 7,1 & 7,2 & 7,1 \\
\hline \multicolumn{10}{|c|}{ Oktatásra szánt kiadás } \\
\hline \multirow{6}{*}{ 2. blokk } & Magyarország & 11,2 & 10,3 & 9,7 & 9,3 & 10,3 & 10,3 & 10,5 & 10,8 \\
\hline & Csehország & 11,6 & 11,8 & 11,3 & 12,0 & 12,1 & 11,8 & 11,3 & 11,9 \\
\hline & Lengyelország & 12,1 & 12,4 & 12,5 & 12,4 & 12,4 & 12,7 & 12,1 & 11,9 \\
\hline & Szlovákia & 9,9 & 10,1 & 10,0 & 9,5 & 9,8 & 9,3 & 9,3 & 9,4 \\
\hline & Ausztria & 9,7 & 9,8 & 9,8 & 9,7 & 9,4 & 9,6 & 9,8 & 9,9 \\
\hline & Németország & 9,2 & 9,6 & 9,5 & 9,6 & 9,6 & 9,5 & 9,4 & 9,3 \\
\hline \multicolumn{10}{|c|}{$\begin{array}{l}\text { Egészségügyre szánt } \\
\text { kiadás }\end{array}$} \\
\hline \multirow{6}{*}{ 3. blokk } & Magyarország & 10,2 & 10,3 & 10,6 & 10,2 & 9,7 & 10,4 & 10,3 & 10,2 \\
\hline & Csehország & 17,9 & 17,9 & 17,4 & 17,9 & 17,9 & 18,1 & 18,9 & 19,2 \\
\hline & Lengyelország & 10,9 & 10,6 & 10,8 & 10,9 & 10,9 & 11,2 & 11,3 & 11,4 \\
\hline & Szlovákia & 17,1 & 16,7 & 16,7 & 16,5 & 16,7 & 15,8 & 17,7 & 17,7 \\
\hline & Ausztria & 14,9 & 15,0 & 15,0 & 15,1 & 15,1 & 16,0 & 16,3 & 16,6 \\
\hline & Németország & 14,7 & 15,2 & 15,4 & 15,7 & 16,2 & 16,3 & 16,2 & 16,2 \\
\hline \multicolumn{10}{|c|}{ K+F-re szánt kiadás } \\
\hline \multirow{6}{*}{ 4. blokk } & Magyarország & 1,1 & 1,2 & 1,3 & 1,4 & 1,4 & 1,4 & 1,2 & 1,4 \\
\hline & Csehország & 1,3 & 1,6 & 1,8 & 1,9 & 2,0 & 1,9 & 1,7 & 1,8 \\
\hline & Lengyelország & 0,7 & 0,8 & 0,9 & 0,9 & 0,9 & 1,0 & 1,0 & 1,0 \\
\hline & Szlovákia & 0,6 & 0,7 & 0,8 & 0,8 & 0,9 & 1,2 & 0,8 & 0,9 \\
\hline & Ausztria & 2,7 & 2,7 & 2,9 & 3,0 & 3,1 & 3,1 & 3,1 & 3,2 \\
\hline & Németország & 2,7 & 2,8 & 2,9 & 2,8 & 2,9 & 2,9 & 2,9 & 3,0 \\
\hline \multicolumn{10}{|c|}{ Versenyképességi pozíció } \\
\hline \multirow{6}{*}{ 5. blokk } & Magyarország & 42 & 47 & 45 & 50 & 48 & 48 & 46 & 52 \\
\hline & Csehország & 29 & 30 & 33 & 35 & 33 & 29 & 27 & 28 \\
\hline & Lengyelország & 32 & 34 & 34 & 33 & 36 & 33 & 33 & 38 \\
\hline & Szlovákia & 49 & 48 & 47 & 47 & 45 & 46 & 40 & 51 \\
\hline & Ausztria & 14 & 18 & 21 & 23 & 22 & 26 & 24 & 25 \\
\hline & Németország & 16 & 10 & 9 & 9 & 6 & 10 & 12 & 13 \\
\hline
\end{tabular}

Forrás: a szerző szerkesztése 
Milyen tendenciák rajzolódnak ki a 4. táblázatban?

- Magyarország az összes állami kiadásokon belül növekvő arányban költ a gazdaságra.

- A vizsgált országok között 2017-ben Magyarország költötte a legtöbbet a gazdaságra.

- Magyarország változó arányban költ oktatásra: 2010-2014 között csökkenő, 2013 óta növekvő mértékben.

- Legtöbbet oktatásra minden vizsgált évben Lengyelország költött.

- Egészségügyre minden évben Magyarország költött a legkevesebbet. 2015 óta pedig folyamatosan csökkennek az egészségügyi ráfordítások.

- Csehország növekvő mértékben költ egészségügyre.

- Magyarország a V4-ek között, Csehország után a második legtöbbet költ K+Fre GDP-arányosan, viszont lényegesen kevesebbet költ, mint a sokkal versenyképesebb Ausztria és Németország.

- Magyarország a versenyképességi listán 2010 és 2013 között az utolsó előtti, 2014 és 2017 között pedig az utolsó helyen volt.

- A versenyképességi listán az első két helyen Németország és Ausztria, a V4-ek között pedig Csehország található.

Az adatok természetesen további elemzést igényelnek, valamint újabb, a versenyképességet befolyásoló tényezőket is be lehetne vonni az értékelésbe. Azonban úgy tünik, hogy a kutatás-fejlesztési ráfordítások, az ezekkel összefüggésben megvalósuló innováció, továbbá a humán vagyonba történő állami beruházások nagyobb hatással vannak a versenyképességre, mint az állami gazdasági ráfordítások. A további elemzéseket segítenék különböző termelékenységi vizsgálatok, ugyanis az is bizonyított, hogy a termelékenységjavulás is fontos versenyképesség javító feltétel. A termelékenység, különösen az úgynevezett teljes tényezős termelékenység ${ }^{31}$ javítás alapvető feltétele pedig az innováció és a tudásberuházások. ${ }^{32}$

Az állami ráfordítások hatékonyságát nemcsak a gazdaság, hanem a társadalom területén elért fejlődés alapján is értékelhetjük. A társadalom szempontjából fontos, hogy hogyan alakul a humán vagyon.

\section{Ráfordítások és társadalmi hatások}

A mindenkori költségvetés feladatai között találjuk a humán vagyon megőrzését, amelynek egyik módja a várható élettartam növelése. Ez azért is fontos, mert a korai halálozás csökkenti a gazdaságban rendelkezésre álló munkaerő mennyiségét. Az egészségügyi ráfordítások, nem kizárólagosan bár, de hatnak a várható élettartamra éppen úgy, mint az idősekre közvetlenül fordított összegek. A humán vagyon

31 Teljes tényezős termelékenységről bővebben: HüTTL 2017, 576-598.

32 Ezeket „intangible”, azaz nem megfogható beruházásoknak is szokták nevezni. Haskel és Westlake könyvében a „nem megfogható” beruházások növekvő szerepét a versenyképesség javításában. HASKEL-WESTLAKE 2018. 
gyarapításának pedig fontos eszköze a családok és gyermekek támogatása. A továbbiakban nézzünk meg néhány állami kiadási adatot, és azok összefüggéseit ezekkel a fontos társadalmi jellemzőkkel. A humán vagyon akkor gyarapszik, ha nő a születések, és csökken a halálozások száma.

Ezekre az adatokra, nyilván nem kizárólagosan, de hatnak az állam különböző célzott támogatásai. Ilyenek a családokra és gyermekekre, továbbá az idősekre fordított állami kiadások, és általában az egészségügy finanszírozása. A 4. ábrán a családokra és a gyermekekre fordított állami ráfordítások összehasonlító adatait látjuk néhány EU-s ország esetén a 2010-2017-es időtávon. A ráfordításoktól eredményként nyilvánvalóan a termékenységi ráta javulását várjuk.

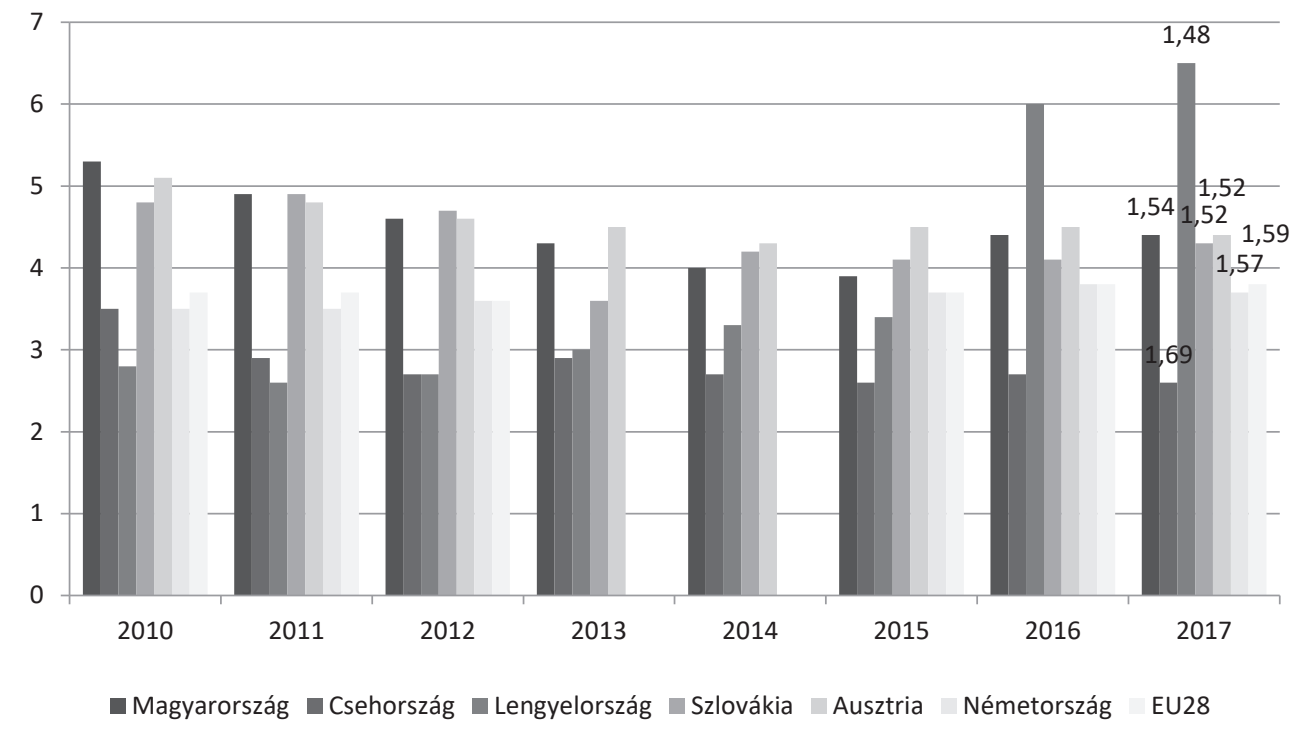

4. ábra: A családokra és gyermekekre forditott állami ráfordítások az összes kiadás arányában és a termékenységi ráta 2017-ben

Forrás: Eurostat alapján a szerző számitása

A 4. ábra alapján azt látjuk, hogy a család- és gyermektámogatásra szánt állami ráfordítások aránya az összes kiadáson belül 2010-ben még Magyarországon volt a legmagasabb. Azóta az arány csökken, bár így is minden évben magas szinten marad. 2017-ben Lengyelország után - Ausztriával egyező szinten - a második legnagyobb. A 2017. évi termékenységi adatok között a magyar a második legmagasabb, az EU28 átlagánál 0,05\%-kal nagyobb érték (1,54). Ez az érték 2010-ben még csak 1,23 volt. Akkor ez volt az ábrán szereplő országok között a legalacsonyabb érték. Érdekes viszont, hogy 2017-ben a legnagyobb érték - 1,69 - Csehországban található, miközben a teljes időszakban Csehország költötte a legkevesebbet az állami kiadások arányában családtámogatásra. 
A humán vagyon megőrzése szempontjából az is fontos, hogy mennyi pénzt szán egy ország az állami kiadásaiból az időskorúakra és az egészségügyre. A 5. ábrán az idősekre fordított állami ráfordításokat látjuk az összes állami kiadás arányában néhány EU-s ország esetén a 2010-2017-es időszakban.

A 2017. évi országadatok felett az adott országra 2017-ben jellemző várható élettartamadatot adatot találjuk.

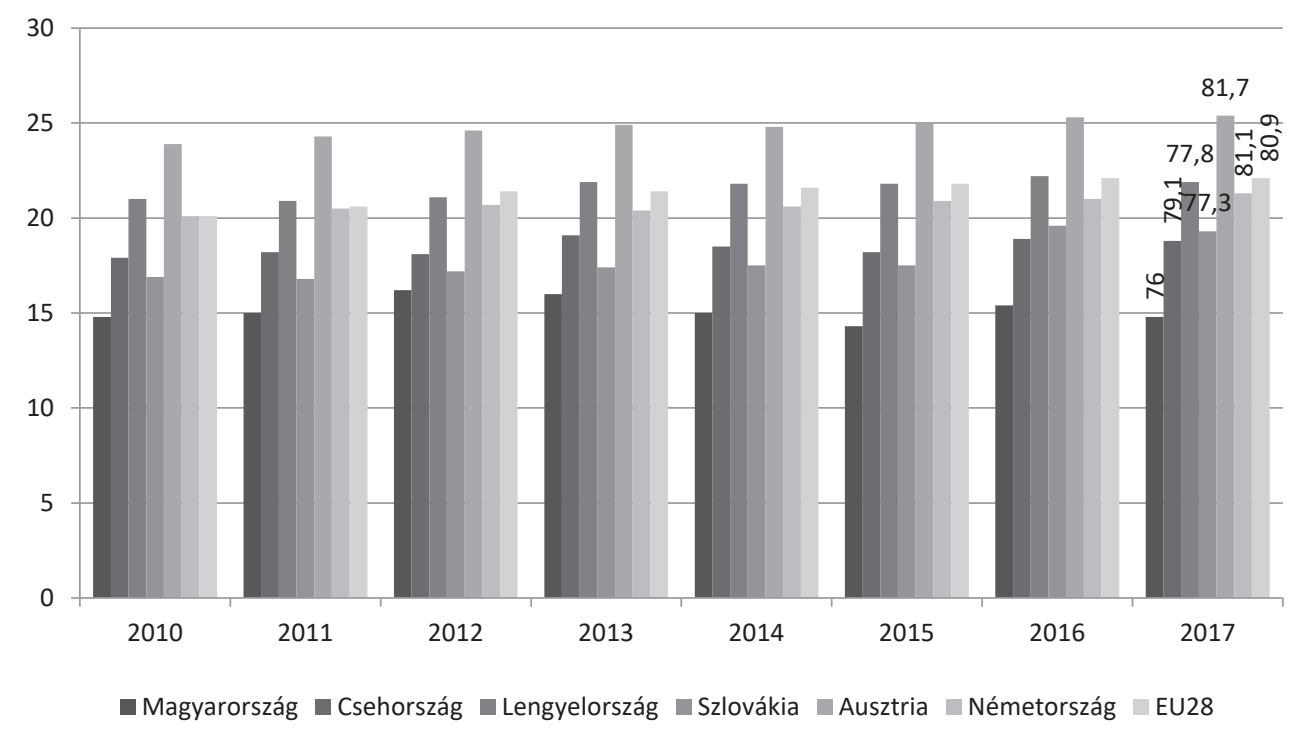

5. ábra: Idösekre forditott állami ráforditások az összes állami kiadás arányában, és a várható élettartam 2017-ben

Forrás: Eurostat

Az adatok szerint a 2010-2017-es időszak valamennyi évében Magyarország költötte a legkevesebbet az időskorúakra az összes állami kiadás arányában. A következő legalacsonyabb értéket Szlovákiánál találjuk. A 2017. évi várható élettartamok között a magyar érték a legalacsonyabb, minket Szlovákia követ.

Ugyanakkor Lengyelország többet fordít az idősekre, de a várható élettartama 2017-ben a harmadik legalacsonyabb. Viszont, ha a várható élettartamot szintén befolyásoló adatsort, az egészségügyre szánt állami kiadásokat is megvizsgáljuk, akkor azt látjuk, hogy a lengyel értékek nagyon alacsonyak.

Az egészségügyi állami ráfordítások és a várható élettartam értékeket a GDP arányában a 2010-2017-es időtávon a 6-7. ábra tartalmazza. Az oszlopok a ráfordítások (6. ábra), a görbék pedig a várható élettartam változását (7. ábra) mutatják a vizsgált időtávon. 


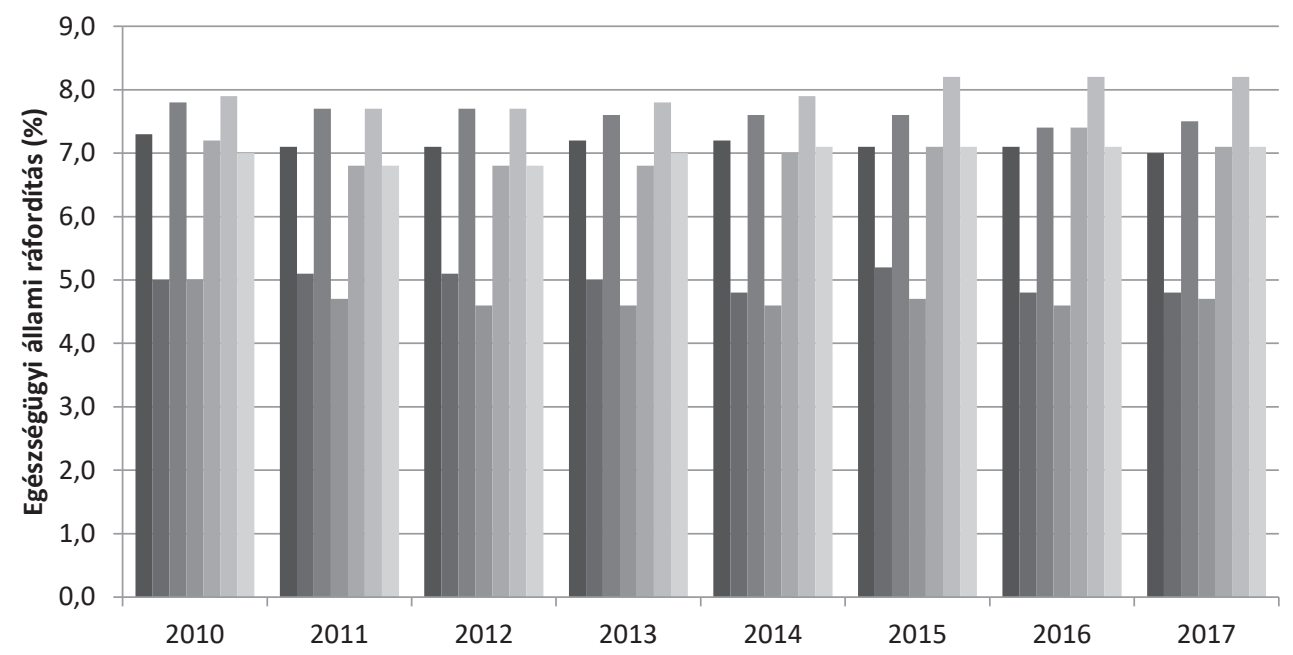

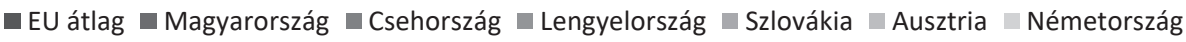

6. ábra: Egészségügyi állami ráfordítások a GDP \%-ában

Forrás: Eurostat alapján a szerző szerkesztése

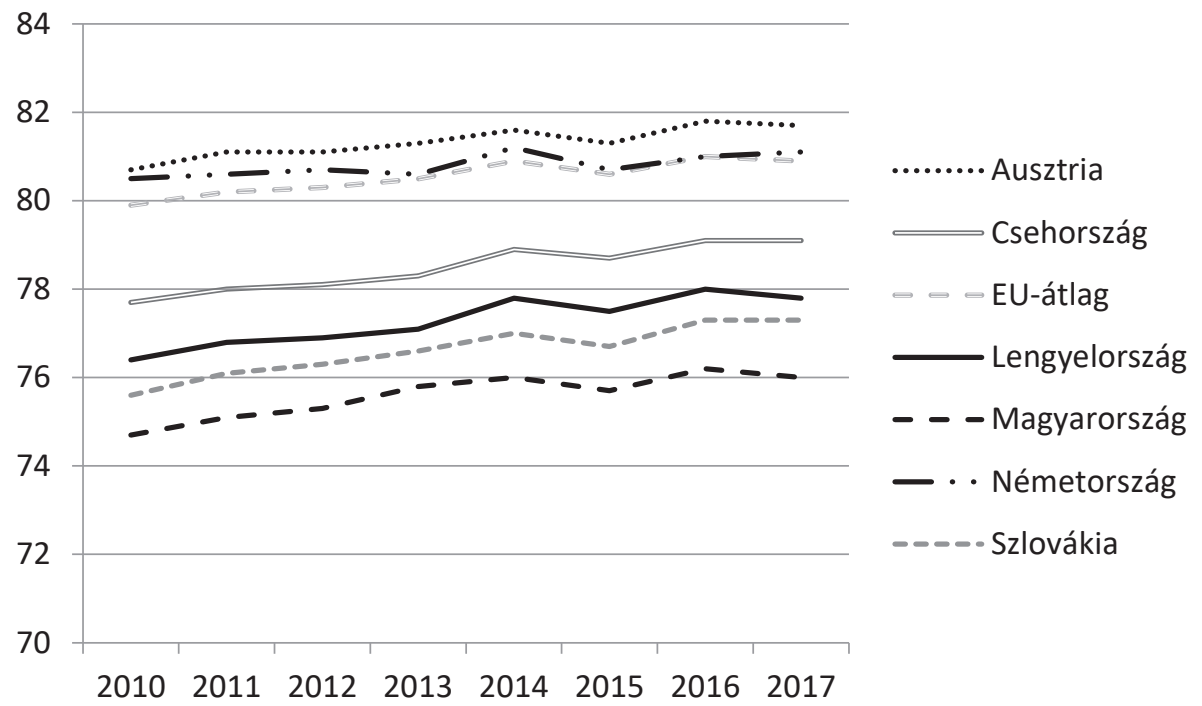

7. ábra: Várható élettartam alakulása (2010-2017)

Forrás: Eurostat alapján a szerző szerkesztése

Azt látjuk, hogy egészségügyre, a GDP arányában Lengyelország után Magyarország fordítja a legkevesebbet minden vizsgált évben. A várható élettartamunk viszont minden évben a legalacsonyabb. A V4-ek között Csehország költi a legtöbbet az összes 
állami kiadás arányában egészségügyre, és lakossága várható élettartama is a legmagasabb. De így sem éri el az osztrák és a német szintet.

Végül nézzünk meg még egy fontos adatsort. A 8. ábrán a 100 ezer (0-69 éves) lakosra jutó, a korai halálozás miatt elveszett évek számát látjuk 2016-ban. Az elveszett évek valójában kieső munkaerőnek tekinthetők. Ezt az adatot az OECD számítja. A mérés úgy történik, hogy választanak a kutatók egy átlagos, 70 éves várható átlagéletkort alapértéknek, majd megnézik, hogy ha elérték volna ezt a korhatárt az ennél fiatalabb korban meghaltak, akkor mennyi többlet munkaórát nyertek volna az egyes országok. A könnyebb nemzetközi összehasonlíthatóság érdekében a mutatót a 100 ezer, a 0-69 éves korcsoportba tartozó lakosra jutó, a korai halálozás miatt elveszett évekkel fejezik ki. A vizsgált 38 ország között a legutolsó, 2016. évi adatok alapján ez az érték Magyarország esetén 4806 év. Ezzel az értékkel a 32. helyen vagyunk, vagyis csak 6 ország adata rosszabb, mint a miénk. Lengyelország 4, Szlovákia 5 és Csehország 9 hellyel előz meg minket az OECD-országok ${ }^{33}$ között.

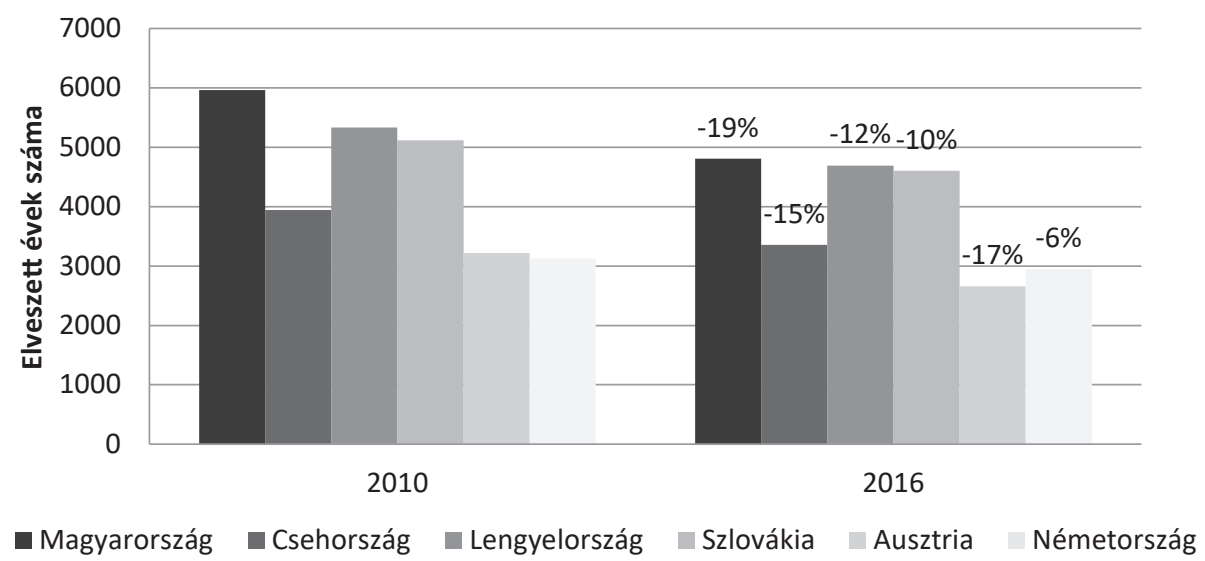

8. ábra: 100 ezer lakosra jutó (0-69 éves) korai halálozás miatt elveszett évek száma 2016-ban, és a 2010 és 2016 közötti változás (\%)

Forrás: Citizen-state relations 2010 alapján a szerző számitása

5. táblázat: A vizsgált országok lakossága (2018. január 1.)

\begin{tabular}{|l|l|}
\hline Magyarország & 9778371 \\
\hline Csehország & 10610055 \\
\hline Lengyelország & 37976687 \\
\hline Szlovákia & 5443120 \\
\hline Ausztria & 8822267 \\
\hline Németország & 82792351 \\
\hline
\end{tabular}

Forrás: a szerző szerkesztése

33 Az OECD-nek 2018-ban 36 tagországa volt. 
A magyar érték, mint látjuk nagyon kedvezőtlen, föleg ha a lakosságszámot is figyelembe vesszük. Ugyanakkor, ahogyan a 2016. évi oszlopok feletti változás adatok mutatják, 2010-ről 2016-ra Magyarország ért el a legnagyobb előrelépést, 19\%-os elveszettév-csökkenést.

\section{Összefoglalás}

A cikk kísérletet tett az állami múködés hatékonyságának az állami kiadások szerkezete nemzetközi összehasonlító elemzésén, továbbá a kiadások és azok gazdaságitársadalmi hatásait mérő néhány jellemző összefüggés vizsgálatán alapuló mérésére. A vizsgálatok alapján néhány figyelemre érdemes következtetést lehetett levonni.

A vizsgált két gazdasági hatásjellemző, a költségvetési hiány és a versenyképesség alakulása volt. A csökkenő tendenciájú, de még mindig magas magyar GDP-arányos állami kiadás, különösen annak nemzetközi összehasonlításban is kiemelkedő mértékủ gazdaságösztönző szelete nem jár együtt az IMD versenyképesség-kutató versenyképességi listáján való előrelépéssel (3. ábra). Ennek nyilvánvaló oka, hogy a versenyképesség javítása hosszabb távú gondolkodást igényel, és nemcsak a gazdaságba, hanem a humán vagyonba és a kutatás-fejlesztésbe történő beruházás magas szintjét is szükségessé teszi. Másrészt a magas GDP-arányos állami kiadások, valamint a még mindig magas költségvetési hiány és adósságszint között is összefüggés mutatható ki. A kiadási szerkezet kapcsán érdemes arra is felfigyelni, hogy Magyarország az EU-s átlagnál GDP-arányosan és a teljes kiadási összegen belül is többet költ közbiztonságra, a kultúra, hitélet és kikapcsolódás kiadási csoportra, viszont lényegesen kevesebbet költ egészségügyre és szociális védelemre (3. táblázat).

A kiadások hatékonyságát a társadalmi hatások oldaláról elemezve pedig összefüggés érzékelhető az egészségügyre és az idősekre nemzetközi összehasonlításban alacsony GDP- és teljeskiadás-arányos ráfordítás, és az alacsony várható élettartam, valamint a korai halálozások miatti jelentős munkaerő-veszteség között. Természetesen az összefüggésrendszerben további, nem ráfordítás jellegủ tényezőket is vizsgálni lehetne.

A családtámogatások és a termékenységi ráta folyamatos javulása között is összefüggés mutatható ki. Viszont érdemes felfigyelni a cseh adatra: alacsonyabb családtámogatási ráfordítás mellett jobb termelékenységi rátát érnek el. Az eltérést további okok, például a választott családtámogatási modellek összehasonlításával lehetne megvilágítani.

Az összefüggések további elemzése során lehetne kitérni arra is, hogy ez a kiadásszerkezet hosszabb távon és fenntartható módon biztosítja-e a gazdaság és a társadalom harmonikus fejlődését, hozzájárul-e a költségvetéssel kapcsolatos emberi jogok érvényesüléséhez, például a társadalmi egyenlötlenségek csökkenéséhez. A további kutatások témája lehetne végül az is, hogy a magas GDP-arányos állami kiadás és az állami intézményrendszer szerkezete, működési hatékonysága és a bürokrácia mértéke milyen kapcsolatban van egymással. 


\section{Felhasznált irodalom}

Accountability and Democratic Governance: Orientations and Principles for Development (2014). Paris, OECD. DOI: https://dx.doi.org/10.1787/9789264183636-en

Acemoglu, Daron - Robinson, James A. (2012): Why Nations Fail. New York, Crown Publishers. Barnett, Chris - Barr, Julian - Angelo, Christie - Duff, Belinda - Hext, Shaun (2010): Measuring the Impact and value for Money of Governance \& Conflict Programmes. UK Goverment, VFM Report. Elérhető: https://assests.publishing.service.gov.uk (2019. 06. 10.)

Boadway, Robin - Wildasin, David (1984): Public Sector Economics (2nd.ed). Little, Brown and Company

Citizen-state relations: Improving Governance through Tax Reform (2010). Paris, OECD.

Csatr Magdolna (2018): Tudás- és innovációalapú versenyképesség. Pénzügyi Szemle, 63. évf. 1. sz. 65-79.

Di Matteo, Livio (2013): Measuring government in the 21st century. Vancouver, Canada, Fraser Institute.

Farrell, Diana - Goodman, Andrew (2013): Government by design: Four principles for a better public sector. Washington, D.C., McKinsey \& Company.

Haskel, Jonathan - Westlake, Stian (2018): Capitalism without Capital: The Rise of the Intangible Economy. Princeton-Oxford, Princeton University Press. DOI: https://doi. org/10.1515/9781400888320

HÜтTL Antónia (2017): A termelékenység számítás néhány koncepcionális kérdése és statisztikai vonatkozása. Statisztikai Szemle, 95. évf. 6. sz. 576-598. DOI: https://doi.org/10.20311/ stat2017.06.hu0576

Kaufmann, Daniel - KraAy, Aar - Mastruzzi, Massimo (2010): The Worldwide Governance Indicators: Methodology and Analytical Issues. Policy Research working paper. No. WPS 5430. World Bank. Elérhető: https://openknowledge.worldbank.org/handle/10986/3913 (2019. 06. 07.)

Mazzucato, Mariana (2011): The Entrepreneurial State. London, Demos. DOI: https://doi. org $/ 10.3898 / 136266211798411183$

Mazzucato, Mariana (2017): Mission-Oriented Innovation Policy: Challenges and Opportunities. UCL Institute for Innovation and Public Purpose Working Paper (2017-1). Elérhető: www.ucl. ac.uk (2018. 06. 19.)

Newell, Peter - Wheeler, Joanna (2006): Taking Accountability into Account. In NeWELL, Peter WheELER, Joanna eds.: Rights, Resources and the Politics of Accountability. London, Zed Books.

Palotai Dániel - Virág Barnabás (2016): Versenyképesség és növekedés. Budapest, MNB.

Program a versenyképesebb Magyarországért (2019). Magyarország Kormánya. Elérhető: www. kormany.hu/download/7/91/91000/Program\%20a\%20Versenyk\%C3\%A9pesebb\%20Magyarorsz\%C3\%A1g\%C3\%A9rt.pdf\#!DocumentBrowse (2019. 05. 30.)

Rothstein, Bo - Teorell, Jan (2008): What is Quality of Government? A Theory of Impartial Government Institutions. Governance, Vol. 21, No. 2. 165-190. DOI: https://doi.org/10.1111/ j.1468-0491.2008.00391.x

Schiavo-Campo, Salvator (2017): Government Budgeting and Expenditure Management. New York - London, Routledge. DOI: https://doi.org/10.4324/9781315645872

TAnzi, Vito - Schuknecht, Ludger (1997): Reconsidering the Fiscal Role of Government: The International Perspective. American Economic, Vol. 87, No. 2. 164-168.

Realizing Human Rights Through Government Budgets (2017). New York, Geneva, United Nations.

WALKer, Stephen (2016): Data will only get us so far. We need it to be open. Geneva, World Economic Forum.

World Competitiveness Yearbook 2019 (2019). IMD. Lausanne. Switzerland. Elérhető: www.imd. org/wcc (2019. 06. 01.) 